\title{
Ландшафтное районирование Приморского края
}

\begin{abstract}
Отражены итоги многолетних исследований природных ландшафтов и их геоэкологических изменений при освоении минерально-сырьевых ресурсов. Приведены данные картографирования компонентов ландмафта, таких как фундамент, климат, рельеф, почвы, растительность, и результаты составленной ландшафтной карты Приморского края масштаба $1: 500$ 000, а также физико-географического районирования в масштабе 1 : 1000 000. Дана характеристика 2 типов, 4 классов, 12 родов ландшафтов. Выделяются также 94 вида и 3043 индивидуальных ландшафта.

Ключевые слова: ландиафт, геоэкология, минеральный ресурс, ландшафтная карта.
\end{abstract}

Landscape zonation of Primorsky Krai. V.T.STAROZHILOV (Far Eastern National University, Vladivostok).

The work reflects the results of long-term studies of the natural landscapes and their geoecological changes by the development of mineral resources. It presents the data of mapping of landscape components, such as basal complex, climate, relief, soils, vegetation and the results of landscape mapping of Primorsky Krai (the map scaled 1:500,000), as well as physical-geographical mapping (the map scaled 1:1,000,000). 2 types, 4 classes and 12 genera of landscapes are characterized. The results of study of technogenic changes in landscape component sections of the areas of coal industry and ore mining are also presented.

Key words: landscape, geoecology, mineral resource, landscape map.

Важную роль в формировании природопользования дальневосточных территорий играют структура и организация ландшафтов. Они во многом определяют систему характеристик, отражающих степень антропогенной изменчивости ландшафтов, характер и уровни их техногенного загрязнения, особенности геоэкологии. Поэтому изучение структуры и организации ландшафтов актуально. Это в свою очередь дает основание рассматривать итоговые ландшафтные карты как основу, а ландшафты как объекты для изучения территориальной дифференциации условий природы в целом. Для применения результатов ландшафтных исследований при решении прикладных задач нами впервые проведено картографо-информационное отображение компонентов ландшафтов, разработана методика, составлены карта ландшафтов Приморского края в масштабе 1:500 000 и легенда к ней, а также разработана следующая классификация: индивидуальный ландшафт, вид, род, класс, тип ландшафтов. На карте выделено 3043 ландшафта, изучены их структура и организация. На этой основе картографированы физико-географические территории и выделены 4 области, 8 провинций и 54 физико-географических округа. Проведено изучение техногенных нарушений ландшафтов при минерально-сырьевом освоении территорий.

В основу работы положены исследования по изучению ландшафтов нашей страны отечественными учеными В.В.Докучаевым, Л.С.Бергом, Л.Г.Романенко, С.В.Колесником, К.И.Геренчуком, Н.А.Солнцевым, В.Б.Сочавой, А.А.Григорьевым, Г.И.Исаченко и другими географами. При этом использована информация различных организаций (Биолого-почвенного института и Тихоокеанского института географии ДВО РАН, Приморского управления гидрометеослужбы), фондовые материалы геологических служб Приморского края,

СТАРОЖИЛОВ Валерий Титович - кандидат геолого-минералогических наук, доцент (Дальневосточный государственный университет, Владивосток). E-mail: DVGU_fizgeo@mail.ru 
исследования Г.Н.Витвицкого [1], Г.С.Ганешина [2], Г.И.Иванова [4, 5, 11], Г.И.Исаченко [6], А.М.Короткого [7, 8], Н.А.Крейды [9], Г.Э.Куренцовой [6, 10], В.А.Розенберга [12], а также личный опыт составления детальных и средне-мелкомасштабных карт и созданная совместно с В.К.Мостовым карта ландшафтной типизации Приморского края (1983 г.).

При картографировании, исследовании структуры и пространственной организации ландшафтов Приморского края нами изучались соотношения достаточно значимых выборок данных не только по рельефу, растительности и почвам, но и по коренным и рыхлым породам, климату. В геодинамической эволюции территории учитывались особенности формирования вещественных комплексов фундамента ландшафтов и их структурно-тектоническое положение.

В модели эволюции территории [13] основополагающее значение имеет многократное и последовательное наращивание палеоконтинентов. Для лучшего понимания структуры и пространственно-временной организации ландшафтов специально изучался тектонический режим фундамента в кайнозое, предопределивший четвертичные и современные ландшафты Приморья. Здесь можно упомянуть рифтогенную активизацию и флюктуационные горст-грабеновые движения в палеогене и неогене. Активизация приводила к формированию рифтогенных зон, сопровождающихся грабено- и горстообразованием. Заложение сложных грабенов на территории края хорошо фиксируется базитовым магматизмом, продуктами которого сложены многочисленные плато (Шкотовское, Борисовское, Зевинское, Единское, Иссиминское, Бикинское и пр.). После графического отображения компонентов и факторов природы на карте в масштабе $1: 500000$ картографированы индивидуальные ландшафты [14-16]. Они проанализированы на качественном и количественном уровнях. Проведен поиск закономерностей в их дифференциации и в конечном итоге изучена структура и пространственная организация ландшафтов Приморья.

Для пространственного анализа ландшафтной структуры использовались ГИС-технологии. Проведено картографо-статистическое изучение ландшафтной карты масштаба 1: 500 000. Особое внимание при расчетах уделялось изучению размеров ландшафтов, их видов, родов, классов, процентному соотношению их площадей в пределах края.

Изучение промышленной минерально-сырьевой геоэкологии выполнено на основе литературных данных, материалов полевых исследований автора и геологических фондов по Приморскому краю.

Ландшафты исследуемой территории в зависимости от физико-географических условий и процессов впервые картографированы 2 типами, 4 классами, 12 родами, 94 видами.

Весь ход геологического, геоморфологического и климатического развития территории Приморского края предопределил формирование и разделение территории на генетические географически целостные и внутренне единые территории. Этому послужили общности исторического развития, географического положения горных складчатых Сихотэ-Алинской и Восточно-Маньчжурской территорий и платформенной равнинной Уссури-Ханкайской. Такое физико-географическое разделение территории Приморского края в свою очередь обусловило развитие горных и равнинных ландшафтов. После их графического отображения и картографирования стало возможным выделить в Приморье границы горного и равнинного типов ландшафтов. Изменяются состояние фундамента, состав и транзит современных осадочных накоплений, тип и интенсивность физического и химического выветривания, пространственное распределение тундровых, таежных, лесных и степных растительных и почвенных группировок. Картографо-информационное их отображение и картографирование отмеченных компонентов во взаимосвязи с климатическим позволило выделить классы ландшафтов: горно-тундровый, горно-таежный, горно-лесной, лесостепной равнинный и горных долин (табл. 1).

Горно-тундровые ландшафты развиты не широко, занимают площадь 608,8 км². Это гольцовые и подгольцовые среднегорные районы с гольцовыми комплексами 
лишайниково-кустарниковых и травянистых группировок и стелющимися лесами, с горно-тундровыми иллювиально-гумусовыми и дерново-органогенными почвами.

Горно-таежные ландшафты развиты широко, площадь их распространения 21 149,4 км². Это среднегорные (массивные и расчлененные) и низкогорные районы с пихтово-еловыми лесами и разнообразными типами почв от горно-таежных бурых иллювиально-гумусовых неоподзоленных и оподзоленных до задернованных и иловато-глеевых.

Горно-лесные ландшафты распространены в крае шире, чем горно-таежные, занимают площадь 98 533,5 км². Это среднегорные (массивные и расчлененные), низкогорные и мелкосопочные районы со сложной дифференциацией растительных и почвенных группировок. Среди растительных группировок преобладают широколиственные леса на бурых лесных почвах.

Ландшафты лесостепных равнин и горных долин занимают площадь 41811,8 км². Это равнинные территории (Уссури-Ханкайская равнина) с типичными для них вейниковоосоковыми, осоковыми, осоково-торфянистыми, лугово-степными ассоциациями и с сохранившимися очагами широколиственных лесов. Почвы в этих ландшафтах от бурых лесных до торфянисто-глеевых. В долинных горных ландшафтах преобладают долинные горные группировки широколиственных лесов и различных пойменных и луговых почв.

Роды ландшафтов неоднородны по пространственной организации растительных и почвенных группировок, представлены 94 видами, в которых картографированы индивидуальные ландшафты.

Следует отметить, что по результатам картографирования и картографо-статистического анализа среди ландшафтов региона наиболее распространены ландшафты низкогорного рода горно-лесного класса (табл. 1). За ними следуют равнинные и долинные горные ландшафты эрозионно-аккумулятивного рода. Наименее развиты ландшафты приморских равнин приморско-равнинного рода, а также близкие по площади и проценту от площади Приморья ландшафты гольцового рода горно-тундрового класса.

Таблица 1

Основные характеристики ландшафтов Приморского края

\begin{tabular}{|c|c|c|c|c|c|c|}
\hline \multirow[t]{2}{*}{ Класс } & \multirow[t]{2}{*}{ Род } & \multicolumn{2}{|l|}{ Площадь } & \multirow{2}{*}{$\begin{array}{l}\text { Преоблада- } \\
\text { ющие абс. } \\
\text { отм., м }\end{array}$} & \multirow{2}{*}{$\begin{array}{l}\text { Глубина } \\
\text { эрозионного } \\
\text { вреза, м }\end{array}$} & \multirow{2}{*}{$\begin{array}{l}\text { Густота гори- } \\
\text { зонтального } \\
\text { расчленения, } \\
\text { км на } 1 \text { км }^{2} \\
\end{array}$} \\
\hline & & $\mathrm{KM}^{2}$ & $\%$ & & & \\
\hline Горно-тундровый & Гольцовый & 608,8 & 0,9 & Более 800 & До 200-300 & $0,4-0,8$ \\
\hline Горно-таежный & $\begin{array}{l}\text { Массивно-среднегор- } \\
\text { ный } \\
\text { Расчлененно-средне- } \\
\text { горный } \\
\text { Низкогорный } \\
\text { Платобазальтовый }\end{array}$ & $\begin{array}{l}3978,9 \\
12208,7 \\
2364,8 \\
2597\end{array}$ & $\begin{array}{l}2,5 \\
15,7 \\
1,5 \\
1,6\end{array}$ & $\begin{array}{l}\text { Более } 800 \\
\text { Более } 800 \\
300-800 \\
\text { До } 1500\end{array}$ & $\begin{array}{l}200-300 \\
300-700 \\
100-400 \\
-\end{array}$ & $\begin{array}{l}0,6-1,0 \\
1,0-2,0 \\
0,4-0,8 \\
0 \text { до } 0,5-0,8\end{array}$ \\
\hline Горно-лесной & $\begin{array}{l}\text { Массивно-среднегор- } \\
\text { ный } \\
\text { Расчлененно-средне- } \\
\text { горный } \\
\text { Низкогорный } \\
\text { Платобазальтовый } \\
\text { Мелкосопочный } \\
\end{array}$ & $\begin{array}{l}8665,7 \\
28628,4 \\
47351,9 \\
9657,9 \\
4229,6 \\
\end{array}$ & $\begin{array}{l}4,3 \\
15,7 \\
27,4 \\
5,0 \\
2,6\end{array}$ & \begin{tabular}{|l} 
Более 800 \\
Более 800 \\
$300-800$ \\
До 1200 \\
- \\
\end{tabular} & $\begin{array}{l}200-300 \\
300-700 \\
100-400 \\
- \\
-\end{array}$ & $\begin{array}{l}0,6-1,0 \\
1,0-2,0 \\
0,4-0,8 \\
- \\
-\end{array}$ \\
\hline $\begin{array}{l}\text { Лесной и лесо- } \\
\text { степной и степной } \\
\text { и горных долин }\end{array}$ & \begin{tabular}{|l|} 
Приморско-равнин- \\
ный \\
Равнинный эрозионно- \\
аккумулятивный
\end{tabular} & $\begin{array}{l}596,1 \\
41215,7\end{array}$ & $\begin{array}{l}0,4 \\
22,4\end{array}$ & - & - & $\begin{array}{l}- \\
-\end{array}$ \\
\hline Всего & & 162103,5 & 100 & & & \\
\hline
\end{tabular}

Примечание. Прочерк - отсутствие данных. 
Виды ландшафтов, так же как и роды, значительно дифференцированы по площади и долевому участию (табл. 2). Кроме того, виды ландшафтов представлены различным количеством индивидуальных ландшафтов: от одного до 223. Отметим также, что в результате исследований картографировано значимое множество ландшафтов. Такая их мелкоконтурность свидетельствует о значительном ландшафтном разнообразии Приморья. В целом изучение и картографо-статистический анализ индивидуальных ландшафтов (их видов, родов, классов и типов), поиск закономерностей их структуры и пространственно-временной организации позволили картографировать физико-географические области, провинции, округа [17].

Понимая целостность природы, определяемую как взаимопроникновение, взаимосвязанность и взаимообусловленность ее компонентов и факторов, автор при районировании учитывал результаты многолетних исследований геодинамической эволюции зоны перехода Азиатского континента к Тихоокеанской структуре [13]. При этом учитывались

Таблица 2

Площадь некоторых видов ландшафтов Приморского края

\begin{tabular}{|c|c|c|c|c|}
\hline \multirow[t]{2}{*}{ Класс } & \multirow[t]{2}{*}{ Род } & \multirow[t]{2}{*}{ Вид } & \multicolumn{2}{|c|}{ Площадь края } \\
\hline & & & кМ2 & $\%$ \\
\hline $\begin{array}{l}\text { Горно-тундро- } \\
\text { вый }\end{array}$ & Гольцовый и подгольцовый & Лишайниково-кустарниковый & 608,8 & 0,4 \\
\hline Горно-таежный & $\begin{array}{l}\text { Массивно-среднегорный } \\
\text { Расчлененно-среднегорный } \\
\text { Низкогорный } \\
\text { Платобазальтовый }\end{array}$ & $\begin{array}{l}\text { Зеленомошный } \\
-/ /- \\
-/ /- \\
-/ /-\end{array}$ & $\begin{array}{ll}3 & 960,5 \\
12 & 047,5 \\
2 & 312,7 \\
2 & 580\end{array}$ & $\begin{array}{l}2,4 \\
7,5 \\
1,5 \\
1,6\end{array}$ \\
\hline Горно-лесной & Массивно-среднегорный & $\begin{array}{l}\text { Широколиственно-кедровый } \\
\text { Широколиственно-кедрово-еловый } \\
\text { Чернопихтово-широколиственный } \\
\text { Грабово-широколиственный } \\
\text { Широколиственный } \\
\text { Лиственнично-хвойно-смешанный } \\
\text { Дубовый } \\
\text { Мелколиственный по гарям } \\
\text { Широколиственно-мелколиственный } \\
\text { Мелколиственный } \\
\text { Пихтово-елово-лиственнично-мелко- } \\
\text { лиственный } \\
\text { Невозобновившихся молодых гарей }\end{array}$ & $\begin{array}{l}2005,3 \\
4138 \\
315 \\
321 \\
94 \\
152 \\
134 \\
445 \\
333 \\
123 \\
417 \\
121 \\
\end{array}$ & $\begin{array}{l}1,25 \\
2,6 \\
0,2 \\
0,2 \\
0,06 \\
0,09 \\
0,09 \\
0,28 \\
0,21 \\
0,08 \\
0,26 \\
0,08\end{array}$ \\
\hline & Низкогорный & $\begin{array}{l}\text { Широколиственно-кедровый } \\
\text { Широколиственно-кедрово-еловый } \\
\text { Грабово-чернопихтово-широколист- } \\
\text { венный } \\
\text { Грабово-широколиственный } \\
\text { Широколиственный с порослевыми } \\
\text { зарослями } \\
\text { Широколиственный с липами, кленом } \\
\text { и дубом } \\
\text { Лиственнично-хвойно-смешанный } \\
\text { Дубовый } \\
\text { Остепненный дубово-березово-разно- } \\
\text { травный } \\
\text { Широколиственно-мелколиственный } \\
\text { Дубовый порослево-кустарниково-за- } \\
\text { рослевый } \\
\text { Мелколиственный } \\
\text { Пихтово-елово-лиственнично-мелко- } \\
\text { лиственный } \\
\text { Освоенных земель }\end{array}$ & $\begin{array}{l}14507 \\
7404 \\
562 \\
2692 \\
388 \\
5167 \\
483 \\
10379 \\
563 \\
816 \\
1217 \\
281 \\
2101 \\
500 \\
\end{array}$ & $\begin{array}{l}9,0 \\
4,6 \\
0,3 \\
1,7 \\
0,2 \\
\\
3,2 \\
0,3 \\
6,4 \\
0,3 \\
0,5 \\
0,7 \\
0,2 \\
1,3 \\
0,3\end{array}$ \\
\hline
\end{tabular}


результаты изучения палеогеографической эволюции фундамента и климата, ответственных за формирование ландшафтов. Именно тектонические режимы приводили к изменению климата от морского к муссонному, а в дальнейшем способствовали разделению территории Приморского края на горную Сихотэ-Алинскую область, равнинную УссуриХанкайскую, горную Восточно-Маньчжурскую, простирающиеся в субмеридиональном направлении, и горную субширотную Южно-Приморскую область. Такое разделение территории по динамике фундамента и климата сочетается с различием областей по рельефу, растительности, почвам и другим компонентам и факторам природы.

Отчетливо картографируется Сихотэ-Алинская физико-географическая область с ее гольцовыми и подгольцовыми, среднегорными, низкогорными и горно-долинными родами и горно-таежными, горно-лесными, лесостепными и степными классами и видами ландшафтов. Им соответствуют хвойные и широколиственные группировки растительности на различных почвах. Также отчетливо картографируется Уссури-Ханкайская равнинная физико-географическая область, развивающаяся в условиях континентального Амуро-Ханкайского рифта Ханкайского массива.

Сихотэ-Алинская физико-географическая область отличается от расположенной западнее Уссури-Ханкайской равнинной области и Восточно-Маньчжурской физико-географической области. Для последней характерны горно-лесные классы и низкогорные роды и виды ландшафтов с широколиственными группировками растительности на бурых лесных и других типах почв.

В отличие от названных областей, обособленная на юге Приморского края сложная по сочетанию родов и видов ландшафтов Южно-Приморская физико-географическая область простирается в субширотном направлении и отличается мягким, влажным климатом. Она характеризуется сочетанием участков от горно-таежных, горно-лесных до лесостепных и степных классов и среднегорных, низкогорных и прибрежных аккумулятивных равнинных родов ландшафтов и их видов.

Изменения в рельефе связаны с перераспределением вынутого из недр или вскрышных работ горных пород, а также строительством промышленных и гражданских объектов. В результате на поверхности возникают котлованы, отвалы вскрышных пород, терриконы, появление которых меняет облик территории горно-рудного предприятия, геохимическую миграцию элементов. Почвы и растительность как компоненты природного ландшафта полностью уничтожаются на месте разрезов, карьеров. Кроме того, отчуждаются земли под отвалы вскрышных пород и, как следствие, на их месте уничтожается растительность.

Рассматривая природные и возникающие при угольном и горно-рудном производстве ландшафты, мы отчетливо видим коренную перестройку первых и формирование новых, уже техногенных, ландшафтов. Отмеченное свидетельствует о том, что для установления измененного состояния ландшафтов необходимо составлять в крупном масштабе новые ландшафтные карты. Только после получения таких картографических документов можно судить об изменении природных компонентов ландшафтов территории не на качественном, а на количественном уровне, а также делать выводы о геоэкологии и об устойчивом развитии территорий уже измененных ландшафтов.

Обсуждая полученный материал в целом, можно сказать, что картографированные нами природные географические тела (ландшафты) постоянно вовлечены в процесс природопользования на всех его циклах и на всех стадиях поисков, освоения и эксплуатации угольных, оловянных, цинковых, вольфрамовых, флюоритовых и других месторождений. В связи с этим встает вопрос о значимости регионального картографирования ландшафтов Приморского края, как и прилегающих территорий, в масштабе $1: 500000$.

Региональные ландшафтные карты являются документами, отображающими текущую ситуацию, позволяющими фиксировать изменения ресурсосодержащих компонентов и выбирать наиболее оптимальные методики эксплуатации ресурсов. 
Итак, системный картографо-ландшафтный подход к изучению природных условий юга Дальнего Востока на региональном уровне, подкрепленный составленными нами ландшафтной картой Приморского края масштаба $1: 500$ 000, легендой к ней и классификацией ландшафтов на уровне типов, классов, родов, видов и индивидуальных ландшафтов, позволяет документально видеть структуру, организацию, в частности дифференциацию ландшафтов, уникальной зоны перехода Азиатского континента к Тихому океану. С помощью полученных теоретических и картографических документов уже сейчас можно изучать равнинные и горные ландшафты юга Дальнего Востока на фундаментальном уровне с нацеливанием таких исследований на прикладное использование. Картографоландшафтные документы могут быть географическим базисом для изучения продолжающихся геоэкологических изменений организованной структуры природопользования в новых условиях хозяйственной политики. Полученные результаты по моделированию ландшафтов и физико-географическому районированию рассматриваются нами как основа не только ландшафтного анализа Приморского края, но и изучения геоэкологии и регионального минерально-сырьевого природопользования. Рекомендуется при природопользовании составлять пятикомпонентные (фундамент, рельеф, климат, почвы, растительность) ландшафтные карты регионального и локального информационного уровней и применять эколого-ландшафтный подход к оптимизации природопользования территорий. Ландшафтные карты, как графические документы, позволят прогнозировать негативные последствия вмешательства в окружающую среду, снизить масштабы техногенного воздействия на ландшафты и оптимально использовать геоэкологический потенциал территории природопользования. Они необходимы при решении стратегических проблем эксплуатации минерально-сырьевых ресурсов на юге Дальнего Востока.

\section{ЛИТЕРАТУРА}

1. Витвицкий Г.Н. Климат // Южная часть Дальнего Востока. М.: Наука, 1969. 235 с.

2. Ганешин Г.С. Геоморфология Приморья // Тр. ВСЕГЕИ. Нов. сер. 1957. Т. 4. С. 1-135.

3. Геоботаническая карта Приморского края. М. 1 : 500000 / под ред. Б.П.Колесникова, Г.Э.Куренцовой. М., 1956.

4. Иванов Г.И. Почвообразование на юге Дальнего Востока. М.: Наука, 1976. 200 с.

5. Иванов Г.И. Почвы Приморского края. Владивосток: Дальиздат, 1964. 107 с.

6. Исаченко Г.И. Основы ландшафтоведения и физико-географическое районирование. М.: Высш. шк., 1965. $368 \mathrm{c}$.

7. Короткий А.М. Корреляция современного рельефа и осадков для целей палеогеографии (на примере горных стран юга Дальнего Востока). Владивосток, 1970. 167 с.

8. Короткий А.М. Палеогеоморфологический анализ рельефа и осадков горных стран (на примере Дальнего Востока). М.: Наука, 1983. 246 с.

9. Крейда Н.А. Почвы хвойно-широколиственных лесов Приморского края. Владивосток, 1970. 228 с. (Уч. зап. ДВГУ; т. 27, ч. 2).

10. Куренцова Г.Э. Растительность Приморского края. Владивосток: Дальиздат, 1968. 192 с.

11. Почвенная карта Приморского края. М. 1 : 500000 / под. ред. Г.И.Иванова. Хабаровск: ГУГК, 1983.

12. Розенберг В.А. К характеристике пихтово-еловых лесов Приморья и Приамурья // Материалы по изучению лесов Сибири и Дальнего Востока. Красноярск, 1963. С. 39-49.

13. Старожилов В.Т. Геодинамическая эволюция зон перехода Северо-Востока Азии к Тихоокеанской плите // Гидрометеорологические и географические исследования на Дальнем Востоке: материалы 5-й юбилейной науч. конф. «К всемирным дням воды». Владивосток, 2004. С. 85-88.

14. Старожилов В.Т. Карта ландшафтная Приморского края масштаба 1 : 1000 000. Владивосток: Изд-во Дальневост. ун-та, 2009.

15. Старожилов В.Т. Карта ландшафтов Приморского края масштаба 1: 500 000. М.: ВНТИЦ, 2007.

16. Старожилов В.Т., Зонов Ю.Б. Карта ландшафтов Приморского края масштаба 1 : 3000000 // Атлас Приморского края: 2-е изд., испр. и доп. Владивосток: ТИГ ДВО РАН, 2008.

17. Старожилов В.Т., Зонов Ю.Б. Карта физико-географического районирования масштаба $1: 8000000$ Приморского края // Атлас Приморского края: 2-е изд., испр. и доп. Владивосток: ТИГ ДВО РАН, 2008. 